\title{
EFFECT OF SOWING DATE OF SWEET CORN ON POTATO + SWEET CORN INTERCROPPING SYSTEM
}

\author{
A.A. Begum, M.N. Islam, S.S. Kakon, M.A.H.M. Kamal ${ }^{1}$, M.A. Aziz and S.K. Paul \\ Agronomy Division, Bangladesh Agricultural Research Institute, Gazipur \\ Agronomy Division, RARS, Burirhat, Rangpur \\ Corresponding author: luckyshamol6869@gmail.com
}

Key words: Sowing date, Light availability, Intercropping, Potato equivalent yield, LER, Potato and Sweet corn

\begin{abstract}
An experiment was conducted at the Agronomy research field of Bangladesh Agricultural Research Institute (BARI), Joydebpur, Gazipur and at Regional Agricultural Research Station, Burirhat, Rangpur during Rabi season of 2013-14 and 2014-15 to find out optimum sowing date of sweet corn in potato + sweet corn intercropping system for getting maximum yield and economic return. Six treatments viz., simultaneous sowing of potato and sweet corn, sweet corn sown at 10 days after potato planting (DAPP), sweet corn sown 20 DAPP, sweet corn sown 30 DAPP, sole potato and sole sweet corn were tested in this study. Sweet corn sown at 20 DPP produced the highest potato equivalent yield (Joydebpur: $41.41 \mathrm{tha}^{-1}$ in 2013-14 and 42.22 $\mathrm{t} \mathrm{ha}^{-1}$ in 2014-15 and Rangpur: $42.29 \mathrm{t} \mathrm{ha}^{-1}$ in 2013-14 and $42.52 \mathrm{t} \mathrm{ha}^{-1}$ in 2014-15). The highest gross return at Joydebpur Tk. 431050 ha $^{-1}$ and at Rangpur Tk. 436248 $\mathrm{ha}^{-1}$, gross margin at Joydebpur Tk. $286805 \mathrm{ha}^{-1}$ and at Rangpur Tk. $271985 \mathrm{ha}^{-1}$ and benefit cost ratio at Joydebpur 2.99 and at Rangpur 3.01 were observed over the years in the same treatment. In this treatment, tuber yield was reduced $3.4-4.1 \%$ in Joydebpur and $7.8-8.4 \%$ in Rangpur due to intercropping. The result indicated that sweet corn sown 20 DAPP might be suitable intercrop combination for getting maximum yield and economic return.
\end{abstract}

\section{Introduction}

Population in Bangladesh is increasing at an alarming rate that demands more food. Intercropping system is one of the important approaches of cropping systems by which production can be increased substantially. Intercropping system becomes productive and economic only when it is done properly by selecting compatible crops (Santalla et al., 2001), by shifting the period of peak demand for growth resources through changing the time of sowing of the component crops (Santalla et al., 1999). Potato (Solanum tuberosum L.) is the third important vegetable crop in Bangladesh in respect of area and production (FAO, 2008). The area under potato is increasing rapidly and the farmers are gradually adopting it as a cash crop. Sweet corn is a unique crop because of its versatile use and low cost per unit production. It is a good source of vitamin C and vitamin A (Chrispher et al., 1996) in the human diet either as a fresh or processed product. In addition, sweet corn plants can be used as a green forage crop. The climatic condition in Bangladesh is suitable for corn cultivation round the year. But there is a problem in increasing area under sweet corn in the country as it has to compete with a number of crops particularly in the dry season (Rabi season). However, the area and production of sweet corn can be increased if it is included as an intercrop with potato. Sowing of component crops at different times is an important agronomic approach in intercropping systems for increasing total productivity. But appropriate sowing time of sweet corn as intercropped with potato has not been extensively studied in Bangladesh. Hence, to find out suitable sowing date of sweet corn as intercropped with potato, this experiment was undertaken for getting maximum yield and economic return.

\section{Materials and Methods}


Begum et al.

The experiment was conducted at the Agronomy Research field of Bangladesh Agricultural Research Institute (BARI), Joydebpur, Gazipur and Regional Agricultural Research Station, Burirhat, Rangpur during Rabi season of 2013-14 and 2014-15. Six treatments viz., simultaneous sowing of potato and sweet corn, sweet corn sown at 10 days after potato planting (DAPP), sweet corn sown at 20 DAPP, sweet corn sown at 30 DAPP, sole potato and sole sweet corn were tested. The experiment was laid out in randomized complete block design with three replications. The unit plot size was $6.0 \mathrm{~m} \times 5.0$ $\mathrm{m}$. The potato var. BARI Alu-7 (Diamant) and sweet corn var. BARI Sweet corn-1 was used. Potato in all the treatments was planted on 24 November 2013 and 17 November 2014 at Joydebpur and on 20 November 2013 and 17 November 2014 at Burirhat. Sweet corn was sown according to the treatments. Sole sweet corn was sown on the date of potato planting. Potato was planted with $60 \mathrm{~cm} \times$ $25 \mathrm{~cm}$ spacing in sole and $75 \mathrm{~cm} \times 20 \mathrm{~cm}$ spacing in intercrop situation. Sweet corn was sown with 75 $\mathrm{cm} \times 20 \mathrm{~cm}$ spacing both in sole and intercrop situation. In intercrop treatments, one row of sweet corn was accommodated in between two rows of potato. For sole potato and sole sweet corn fertilizers were applied @ $\mathrm{N}_{180} \mathrm{P}_{40} \mathrm{~K}_{180} \mathrm{~S}_{20} \mathrm{Zn}_{6} \mathrm{~B}_{1.2}$ and $\mathrm{N}_{160} \mathrm{P}_{50} \mathrm{~K}_{100} \mathrm{~S}_{40} \mathrm{Zn}_{4} \mathrm{~B}_{2} \mathrm{~kg} \mathrm{ha}^{-1}$, respectively (FRG, 2012). For intercrop fertilizers were applied @ $\mathrm{N}_{320} \mathrm{P}_{73} \mathrm{~K}_{170} \mathrm{~S}_{50} \mathrm{Zn}_{6} \mathrm{~B}_{2} \mathrm{~kg}^{-1}$. The source of N, P, K, S, Zn and B was urea, TSP, MoP, gypsum, zinc sulphate and boric acid, respectively. In case of sole potato, half amount of urea and MoP and the whole amount of TSP, gypsum, zinc sulphate and boric acid were applied at the time of final land preparation. Remaining 1/2 amount of urea and MoP were applied at 30 days after sowing (DAS). For sole sweet corn, one-third of urea and whole amount of other fertilizers were applied at the time of final land preparation. Remaining $2 / 3$ amount of urea was applied in two equal splits as side dressing at 30 and 55 days after sowing (DAS). In case of intercrop, one- third urea and of all other fertilizers were applied as basal. One-third urea and rest of all other fertilizers were side dressed at 30 DAP of potato and rest of urea was side dressed just after potato harvest followed by irrigation. Irrigation and other intercultural operations were done as and when required. Fungicide (Dithane M-45) was sprayed at every 10-day intervals beginning from 25 to 70 DAP for preventing disease of potato. All data were taken at harvesting. Potato was harvested at 90 DAP at both the location yearwise. Sweet corn was harvested at 115-120 DAS in both locations. Light availability was measured by PAR Ceptometer (Model - LP-80, Accu PAR, Decagon, USA). Economic analysis was also done. Potato equivalent yield was computed based on prevailing market price of both the crops by the following formula of Bandyopadhyay (1984) as given below:

Potato equivalent yield $=$ Yip $+($ Yisc $\times$ Psc $) / \mathrm{Pp}$

Where, Yip $=$ Yield of intercrop potato, Yisc $=$ Yield of intercrop sweet corn,

$\mathrm{Pp}=$ Market price of potato and Psc $=$ Market price of sweet corn .

\section{Results and Discussion}

\section{Light availability}

Irrespective of treatments, availability of light on potato canopy was almost $100 \%$ at earlier growth stage of potato i.e. 30 DAPP and it decreased with the increase of shade produced by sweet corn. Among treatments, light availability on potato canopy was more in the treatment where sweet corn was sown 30 DAPP throughout growing period and minimum in treatment where potato and sweet corn was planted on same date. It indicated that light availability on potato canopy throughout the crop period, increased with the delay sowing of sweet corn compared to simultaneous sowing (Fig.1). 
Effect of Sowing Date of Sweet Corn on Potato + Sweet Corn Intercropping System

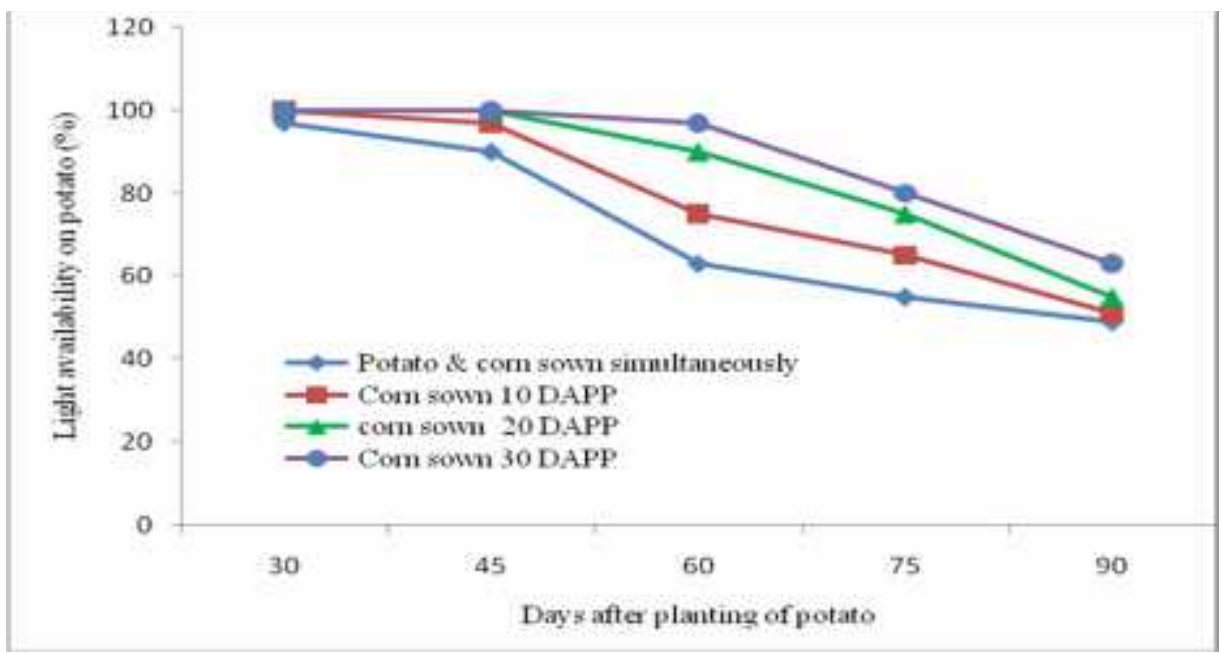

Fig. 1. Light availability on potato plant in potato + sweet corn intercropping at Joydebpur

\section{Effect on tuber yield and yield components of potato}

Yield and yield components of potato were significantly affected in potato/sweet corn intercropping systems in both locations (Table $1 \& 2$ ). The highest number of tubers/hill of potato was observed where sweet corn sown at 30 DAPP followed by sole potato and sweet corn sown 20 DAPP and the lowest in potato and sweet corn sown simultaneously at Joydebpur location. Similar trend was observed in tuber weight/hill. But at Rangpur, significantly the highest number of tuber/hill and weight of tuber hill $^{-1}$ were recorded in sole potato. These parameters were reduced with earlier planting of sweet corn in between two potato rows in both locations and years. The lower values of those parameters might be due to the shading effect of sweet corn plants as well as inter specific competition. At Joydebpur, the results indicated that potato yield was higher than sole potato when sweet corn sown 30 days after potato planting followed by sole potato in both the years $\left(25.00 \mathrm{t} \mathrm{ha}^{-1}\right.$ in 2013-14 and 26.31 t ha ${ }^{-1}$ in 2014-15). It might be for lower temperature due to shading during later growth stage of potato which favoured tuber bulging for longer period and ultimately increased tuber yield when sweet corn sown 30 days after potato planting. Kuruppuarachchi (1990) also observed similar results in potato + maize intercropping. He reported that higher tuber yield was recorded where corn sown 14 days after potato planting. On the contrary, the highest tuber yield $\left(28.84 \mathrm{t} \mathrm{ha}^{-1}\right.$ and $29.25 \mathrm{t} \mathrm{ha}^{-1}$ in 2013-14 and 2014-15, respectively) was observed in sole potato at Rangpur. Tuber yield in sole potato was statistically identical with the treatment where sweet corn sown 30 days after potato planting in 2014-15. Corn sown simultaneously with potato gave the lowest tuber yield was observed in both locations. It might be due to less availability of light on potato canopy during tuber bulging period which reduced tuber yield (Fig.1). Tuber yield in different treatments were attributed to the cumulative effect of yield components viz., number of stems/hill, number of tuber hill ${ }^{-1}$ and tuber weight hill ${ }^{-1}$.

Table 1. Yield and yield components of potato in potato + sweet corn intercropping under different sowing date of sweet corn in Rabi season at Joydebpur

\begin{tabular}{|c|c|c|c|c|c|c|c|c|}
\hline \multirow{2}{*}{$\begin{array}{l}\text { Sweet corn } \\
\text { planting } \\
\text { (days after } \\
\text { potato) }\end{array}$} & \multicolumn{2}{|c|}{$\begin{array}{c}\text { Tubers hill }^{-1} \\
\text { (no.) }\end{array}$} & \multicolumn{2}{|c|}{$\begin{array}{l}\text { Tuber wt. hil }{ }^{-1} 1 \\
\text { (g) }\end{array}$} & \multicolumn{2}{|c|}{$\begin{array}{l}\text { Tuber yield } \\
\qquad\left(\mathrm{t} \mathrm{ha}^{-1}\right)\end{array}$} & \multicolumn{2}{|c|}{$\begin{array}{c}\text { Yield } \\
\text { increase/decrease } \\
\text { over sole potato }(\%)\end{array}$} \\
\hline & 2013-14 & 2014-15 & 2013-14 & 2014-15 & 2013-14 & $2014-15$ & 2013-14 & $2014-15$ \\
\hline Same time & 7.0 & 8.5 & 363.12 & 409.20 & 19.32 & 20.01 & -21.8 & -21.3 \\
\hline
\end{tabular}


Begum et al.

\begin{tabular}{lcccccccc}
10 days & 7.1 & 9.3 & 375.12 & 437.87 & 21.36 & 23.12 & -13.6 & -9.1 \\
20 days & 7.8 & 9.6 & 416.17 & 464.53 & 23.71 & 24.58 & -4.1 & -3.4 \\
30 days & 9.0 & 11.3 & 440.10 & 538.00 & 25.00 & 26.31 & +1.1 & +3.4 \\
Sole potato & 8.5 & 10.8 & 431.15 & 492.40 & 24.72 & 25.44 & - & - \\
\hline LSD $_{(0.05)}$ & 1.34 & 0.80 & 38.82 & 38.44 & 3.01 & 3.10 & - & - \\
CV $(\%)$ & 6.19 & 2.97 & 3.50 & 3.00 & 4.81 & 4.74 & - & - \\
\hline
\end{tabular}

(-) indicates yield decrease, $(+)$ indicates yield increase

Table 2. Yield and yield components of potato in potato + sweet corn intercropping under different sowing date of sweet corn in Rabi season at Rangpur

\begin{tabular}{l|c|c|c|c|c|c|cc}
\hline $\begin{array}{c}\text { Sweet corn } \\
\text { planting } \\
\text { (days after } \\
\text { potato) }\end{array}$ & \multicolumn{2}{|c|}{$\begin{array}{c}\text { Tuber hill }^{-1} \\
\text { (no) }\end{array}$} & \multicolumn{2}{c|}{$\begin{array}{c}\text { Tuber hill } \\
(\mathrm{g})\end{array}$} & \multicolumn{2}{c}{$\begin{array}{c}\text { Tuber yield } \\
\left(\mathrm{t} \mathrm{ha}^{-1}\right)\end{array}$} & \multicolumn{2}{c}{$\begin{array}{c}\text { Yield } \\
\text { increase/decrease } \\
\text { over sole potato }(\%)\end{array}$} \\
\cline { 2 - 10 } & $2013-14$ & $2014-15$ & $2013-14$ & $2014-15$ & $2013-14$ & $2014-15$ & $2013-14$ & $2014-15$ \\
\hline Same time & 7.59 & 8.01 & 336.79 & 338.24 & 21.12 & 22.45 & -26.8 & -23.2 \\
10 days & 8.48 & 8.87 & 376.61 & 381.15 & 24.21 & 23.72 & -16.0 & -18.9 \\
20 days & 8.52 & 9.27 & 423.46 & 432.43 & 26.43 & 26.96 & -8.4 & -7.8 \\
30 days & 8.71 & 9.51 & 432.72 & 451.40 & 26.56 & 27.15 & -7.9 & -3.1 \\
Sole potato & 8.77 & 10.17 & 460.18 & 469.82 & 28.84 & 29.25 & - & - \\
\hline LSD $(0.05)$ & 0.69 & 0.85 & 23.27 & 29.35 & 2.06 & 2.48 & & - \\
CV (\%) & 4.51 & 4.94 & 3.15 & 3.76 & 4.47 & 5.10 & - & - \\
\hline
\end{tabular}

(-) indicates yield decrease, $(+)$ indicates yield increase

\section{Effect on yield and yield components of sweet corn}

Number of cobs $\mathrm{m}^{-2}$, weight of single cob with husk, yield of cob with husk of sweet corn and green fodder yields were influenced significantly under different intercropping systems (Table 3 \& 4). The number of cobs per unit area in all the treatments was similar except sweet corn sown 30 days after potato planting in both locations. The lowest number of cobs $\mathrm{m}^{-2}$ (5.57 in 2013-14 and 5.50 in 201415 at Joydebpur and at Rangpur 5.49 in 2013-14 and 5.51 in 2014-15) in sweet corn sown 30 days after potato planting was found might be due to lower number of maize population per unit area. In this treatment, germination of sweet corn was affected and seedlings growth was hampered due to heavy shading produced by potato canopy that resulted poor growth and less number of cobs $\mathrm{m}^{-2}$. Similar result was reported by Zaag and Demagante (1990). The highest single cob weight was observed in sole corn in both year and the locations which might be due to wider spacing which helped to provide more light and nutrients to crop plants. The maximum cob yield (with husk) was found in sole sweet corn in both locations (17.21 t ha ${ }^{-1}$ in 2013-14 and 17.10 $\mathrm{t} \mathrm{ha}^{-1}$ in 2014-15 at Joydebpur and at Rangpur, $15.08 \mathrm{t} \mathrm{ha}^{-1}$ in 2013-14 and $14.76 \mathrm{t} \mathrm{ha}^{-1}$ in 2014-15) and it was statistically similar with potato + sweet corn sown simultaneously at Joydebpur. The lowest cob yield in sweet corn sown 30 days after potato planting in both locations might be due to cumulative effect of lower yield contributing characters. Similar trend was observed in case of green fodder yield. Yield of cobs gradually decreased with delay in sowing time of sweet corn owing to shorter growth duration and higher temperature at later growth stages. Islam (2002) also reported similar results in maize + bush bean intercropping system. Ifenkwe and Odurukwe (1990) reported that potato yields increased with delay sowing in association with maize while maize yields decreased as its sowing date was delayed.

Table 3. Yield and yield components of sweet corn in potato+ sweet corn intercropping under different sowing dates of sweet corn in Rabi season at Joydebpur

\begin{tabular}{c|c|c|c|c}
\hline $\begin{array}{c}\text { Sweet corn } \\
\text { planting } \\
\text { (days after }\end{array}$ & $\begin{array}{c}\text { Cobs } \mathrm{m}^{-2} \\
\text { (no.) }\end{array}$ & $\begin{array}{c}\text { Single cob weight } \\
\text { with husk } \\
(\mathrm{g})\end{array}$ & $\begin{array}{c}\text { Yield of cob with } \\
\text { husk } \\
\left(\mathrm{t} \mathrm{ha}^{-1}\right)\end{array}$ & $\begin{array}{c}\text { Green fodder yield } \\
\left(\mathrm{t} \mathrm{ha}^{-1}\right)\end{array}$ \\
\hline
\end{tabular}


Effect of Sowing Date of Sweet Corn on Potato + Sweet Corn Intercropping System

\begin{tabular}{l|c|c|c|c|c|c|c|c}
\hline \multicolumn{1}{c|}{ potato) } & $2013-14$ & $2014-15$ & $2013-14$ & $2014-15$ & $2013-14$ & $2014-15$ & $2013-14$ & $2014-15$ \\
\hline Same time & 6.66 & 6.66 & 303.1 & 295.0 & 16.76 & 16.67 & 29.63 & 29.50 \\
10 days & 6.59 & 6.60 & 268.0 & 272.0 & 15.47 & 15.50 & 27.98 & 28.33 \\
20 days & 6.54 & 6.59 & 257.0 & 261.0 & 14.75 & 14.70 & 25.65 & 25.95 \\
30 days & 5.57 & 5.50 & 238.9 & 251.0 & 11.99 & 11.50 & 21.33 & 20.10 \\
Sole sweet corn & 6.66 & 6.66 & 349.8 & 310.0 & 17.21 & 17.10 & 32.10 & 31.50 \\
\hline LSD $_{(0.05)}$ & 0.48 & 0.71 & 73.12 & 24.24 & 2.71 & 1.50 & 5.35 & 3.32 \\
CV $(\%)$ & 2.77 & 4.04 & 9.42 & 3.19 & 6.49 & 3.63 & 7.14 & 4.47 \\
\hline
\end{tabular}

Table 4. Yield and yield components of sweet corn in potato+ sweet corn intercropping under different sowing dates of sweet corn in Rabi season at Rangpur

\begin{tabular}{|c|c|c|c|c|c|c|c|c|}
\hline \multirow{2}{*}{$\begin{array}{l}\text { Sweet corn } \\
\text { planting } \\
\text { (days after } \\
\text { potato) }\end{array}$} & \multicolumn{2}{|c|}{$\begin{array}{l}\text { Cobs m}^{-2} \\
\text { (no) }\end{array}$} & \multicolumn{2}{|c|}{$\begin{array}{c}\text { Single cob weight } \\
(\mathrm{g})\end{array}$} & \multicolumn{2}{|c|}{$\begin{array}{c}\text { Yield of cob with } \\
\text { husk } \\
\left(\mathrm{t} \mathrm{ha}^{-1}\right)\end{array}$} & \multicolumn{2}{|c|}{$\begin{array}{l}\text { Green fodder yield } \\
\left(\mathrm{t} \mathrm{ha}^{-1}\right)\end{array}$} \\
\hline & 2013-14 & 2014-15 & 2013-14 & 2014-15 & 2013-14 & 2014-15 & 2013-14 & 2014-15 \\
\hline Same time & 6.65 & 6.66 & 205.17 & 201.97 & 13.55 & 13.42 & 27.67 & 28.02 \\
\hline 10 days & 6.61 & 6.62 & 202.51 & 197.88 & 13.37 & 13.25 & 26.53 & 26.83 \\
\hline 20 days & 6.58 & 6.60 & 195.56 & 196.12 & 13.22 & 12.97 & 24.18 & 24.45 \\
\hline 30 days & 5.49 & 5.51 & 177.38 & 171.45 & 11.36 & 11.18 & 18.30 & 18.60 \\
\hline Sole sweet corn & 6.65 & 6.67 & 248.29 & 239.89 & 15.08 & 14.76 & 29.70 & 30.00 \\
\hline $\operatorname{LSD}_{(0.05)}$ & 0.69 & 0.65 & 15.22 & 23.50 & 0.96 & 1.42 & 4.99 & 6.10 \\
\hline $\mathrm{CV}(\%)$ & 3.96 & 3.72 & 4.06 & 6.19 & 3.97 & 7.77 & 10.49 & 12.60 \\
\hline
\end{tabular}

Intercrop efficiency

Potato equivalent yield (PEY) and land equivalent ratio (LER) of potato + sweet corn intercropping systems are presented in Table 5. PEY of all the intercropping was higher than sole cropping indicating higher productivity of intercropping than sole cropping. The highest PEY (Joydebpur: 41.41 t ha $\mathrm{ta}^{-1}$ in 2013-14, 42.22 $\mathrm{t} \mathrm{ha}^{-1}$ in 2014-15 and Rangpur: 42.29 $\mathrm{t} \mathrm{ha}^{-1}$ in 2013-14, 42.52 $\mathrm{t} \mathrm{ha}^{-1}$ in 2014-15) and LER (Joydebpur: 1.82 in 2013-14, 1.83 in 2014-15 and Rangpur: 1.80 in both the year) were observed in sweet corn sown 20 days after potato planting. CIMMYT in Bangladesh (2005 and 2006) reported that intercropping maize at 20-35 days after the planting of potato can bring very high

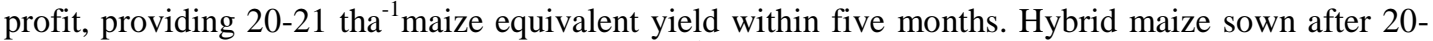
25 days of potato planting gave 31.50-32.80 $\mathrm{tha}^{-1}$ potato equivalent yield (Islam et al., 2010). Begum (2015) found 25.78-31.30 $\mathrm{t} \mathrm{ha}^{-1}$ also when hybrid maize intercropped with potato at 20-30 days after potato planting.

\section{Economic performance}

The economic performance of intercropping system is presented in Table 6 . The highest gross return at Joydebpur Tk. $431050 \mathrm{ha}^{-1}$ and at Rangpur Tk. $436248 \mathrm{ha}^{-1}$, gross margin at Joydebpur Tk. 286805 $\mathrm{ha}^{-1}$ and at Rangpur Tk. $271985 \mathrm{ha}^{-1}$ and benefit cost ratio at Joydebpur 2.99 and at Rangpur 3.01 were observed average over two years in sweet corn sown 20 days after potato planting. Islam et al. (2010) reported that hybrid maize sown after 20-25 days of potato planting gave 4.00-4.23 benefit cost ratio. It was also observed that the highest gross return Tk. $258800-313000 \mathrm{ha}^{-1}$, gross margin Tk. 146478-200678 $\mathrm{ha}^{-1}$ and benefit cost ratio 2.30-2.79.

Table 5. Potato equivalent yield and land equivalent ratio of potato + sweet corn intercropping under different sowing dates of sweet corn in Rabi season at Joydebpur and Rangpur

\begin{tabular}{c|c|c|c|c}
\hline \multirow{2}{*}{$\begin{array}{c}\text { Sweet corn } \\
\text { planting } \\
(\text { days after }\end{array}$} & $\begin{array}{c}\text { Jotato equivalent } \\
\text { yield }\left(\mathrm{t} \mathrm{ha}^{-1}\right)\end{array}$ & LER & $\begin{array}{c}\text { Potato equivalent yield } \\
\left.(\mathrm{t} \mathrm{ha})^{-1}\right)\end{array}$ & LER \\
\hline
\end{tabular}


Begum et al.

\begin{tabular}{l|c|c|c|c|c|c|c|c}
\hline \multicolumn{1}{c|}{ potato) } & $\begin{array}{c}2013- \\
14\end{array}$ & $\begin{array}{c}2014- \\
15\end{array}$ & $\begin{array}{c}2013- \\
14\end{array}$ & $\begin{array}{c}2014- \\
15\end{array}$ & $2013-14$ & $2014-15$ & $\begin{array}{c}2013- \\
14\end{array}$ & $2014-15$ \\
\hline Same time & 39.43 & 40.01 & 1.76 & 1.76 & 37.38 & 38.55 & 1.63 & 1.68 \\
10 days & 39.92 & 41.72 & 1.76 & 1.82 & 40.25 & 39.62 & 1.73 & 1.71 \\
20 days & 41.41 & 42.22 & 1.82 & 1.83 & 42.29 & 42.52 & 1.80 & 1.80 \\
30 days & 39.39 & 40.11 & 1.71 & 1.71 & 40.19 & 40.57 & 1.67 & 1.69 \\
Sole potato & 24.71 & 25.44 & 1.00 & 1.00 & 28.84 & 29.15 & 1.00 & 1.00 \\
Sole sweet corn & 20.65 & 20.52 & 1.00 & 1.00 & 18.10 & 17.71 & 1.00 & 1.00 \\
\hline
\end{tabular}

Market price $\left(\mathrm{Tk} \mathrm{kg}^{-1}\right)$ : Potato $=10$, Sweet corn $=12$, Fodder $=0.50$

Table 6. Economic analysis of potato + sweet corn intercropping under different sowing dates of sweet corn in Rabi season at Joydebpur and Rangpur average over the years

\begin{tabular}{|c|c|c|c|c|c|c|c|c|}
\hline \multirow{2}{*}{$\begin{array}{l}\text { Sweet corn } \\
\text { planting } \\
\text { (days after } \\
\text { potato) }\end{array}$} & \multicolumn{2}{|c|}{$\begin{array}{l}\text { Gross return } \\
\left(\mathrm{Tk} \mathrm{ha}^{-1}\right)\end{array}$} & \multicolumn{2}{|c|}{$\begin{array}{c}\text { Total cost of } \\
\text { production } \\
\left(\mathrm{Tk} \mathrm{ha}^{-1}\right)\end{array}$} & \multicolumn{2}{|c|}{$\begin{array}{l}\text { Gross margin } \\
\left(\mathrm{Tk} \mathrm{ha}^{-1}\right)\end{array}$} & \multicolumn{2}{|c|}{ BCR } \\
\hline & Joydebpur & Rangpur & Joydebpur & Rangpur & Joydebpur & Rangpur & Joydebpur & Rangpur \\
\hline Same time & 411993 & 393613 & 144245 & 145150 & 267748 & 228458 & 2.86 & 2.71 \\
\hline 10 days & 422288 & 412710 & 144245 & 145150 & 278043 & 247853 & 2.93 & 2.84 \\
\hline 20 days & 431050 & 436248 & 144245 & 145150 & 286805 & 271985 & 2.99 & 3.01 \\
\hline 30 days & 407848 & 413015 & 144245 & 145150 & 263603 & 249428 & 2.83 & 2.85 \\
\hline Sole potato & 250750 & 289950 & 128266 & 127250 & 122484 & 162700 & 1.96 & 2.28 \\
\hline $\begin{array}{l}\text { Sole sweet } \\
\text { corn }\end{array}$ & 213885 & 193965 & 104279 & 100250 & 109606 & 105690 & 2.05 & 1.94 \\
\hline
\end{tabular}

Market price $\left(\mathrm{Tk} \mathrm{kg}^{-1}\right)$ : Potato $=10$, Sweet $\operatorname{corn}=12$, Fodder $=0.50$

\section{Conclusion}

Two years results revealed that sowing of sweet corn 20 days after potato planting might be agronomically feasible and economically profitable for sweet corn and potato intercropping system as compared to sole sweet corn in both the location In addition fodder yield could be possible from sweet corn plant to mitigate the livestock feed to some extent.

\section{Reference}

Bandyopadhyay, S. N. 1984. Nitrogen and water relations in grain sorghum legume intercropping systems, $\mathrm{PhD}$ Thesis, Indian Agril. Res. Inst., New Delhi.

Begum, A. A. 2015: Performance of potato maize intercropping as affected by sowing date, row arrangement and fertilizer management, PhD Thesis, Dept. Agron., Bangladesh Agril. Univ., Mymensingh, Bangladesh. pp. 79-82.

Chrispher, R., R. Dowswell, L. Paliwal and P. C. Ronald 1996. Maize in the Third World. Steven A. Breth, Series editor. Westview Press Inc.Colrado USA. p. 23.

CIMMYT Office in Bangladesh 2005. Maize whole family training. In: Food Security in Bangladesh: Improving Wheat, Maize and Papaya Production and Impacts of Arsenic Contamination. Project Annual Report for 2004-2005. pp. 45-66. 
Effect of Sowing Date of Sweet Corn on Potato + Sweet Corn Intercropping System

CIMMYT Office in Bangladesh 2006. Maize whole family training. In: Food Security in Bangladesh: Improving Wheat, Maize and Papaya Production and Impacts of Arsenic Contamination. Project Annual Report for 2005-2006. pp. 31-44.

FAO 2008. Food and Agriculture Organization of the United Nations, Production 2007-2008 Year Book of the Potato, FAO, Rome, Italy. pp. 85-100.

FRG 2012. Fertilizer Recommendation Guide, Bangladesh Agricultural Research Council (BARC), New Airport Road, Farmgate, Dhaka 1215. pp 92-110.

Ifenkwe, O. P. and S. O. Odurukwe 1990. Potato/maize intercropping in the Jos Plateau of Nigeria. Field Crops Res. 25: 73-82.

Islam, M. N. 2002. Competitive interference and productivity in maize-bushbean intercropping system, PhD Thesis, Dept. Agron., Bangabandhu Sheikh Mujibur Rahman Agril. Univ., Gazipur, Bangladesh.

Islam, M. N., F. Ahmed and M. A. Hossain. 2010. Intercropping technologies 2000-2009. Agronomy Division, Bangladesh Agricultural Research Institute, Joydebpur, Gazipur 1701, Bangladesh. pp. $13-15$.

Kuruppuarachchi, D. S. P. 1990. Intercropped potato (Solanum spp.). Effect of shade on growth and tuber yield in the northwestern recosol belt of Sri Lanka. Field Crops Res. 25: 61-72.

Santalla, M., A. P. Rodino, P. A. Casquero and A. M. de Ron 2001. Interactions of bush bean intercropped with field and sweet maize. European J. Agron. 15: 185-196.

Santalla, M., P. A. Casquero and A. M. de Ron 1999. Yield and yield components from intercropping improved bush bean cultivars with maize. Agron. Crop Sci. 183: 263-269.

Zaag, V. P. and A. L. Demagante 1990. Potato (Solanum spp.) in an isohyperthermic environment. V. Intercropping with maize. Field Crops Res. 25: 157-170. 